\title{
ANALISIS SISTEM PENGAWASAN PEMBERIAN PEMBIAYAAN PADA PT BANK SULSELBAR SYARIAH CABANG UTAMA MAKASSAR /
}

\author{
THE SUPERVISION ANALYSIS OF FINANCING IN PT BANK SULSELBAR \\ SYARIAH MAIN BRANCH OF MAKASSAR
}

\author{
Ela Elliyana ${ }^{1}$, Rabia Ahmed Benyahia ${ }^{2}$, Rishka Sri Mulya ${ }^{3}$ \\ ${ }^{1}$ Manajemen Keuangan, Universitas Indonesia Timur \\ (elafaizrayyan@yahoo.com) \\ ${ }^{2}$ Manajemen, Universitas Djilali Bounaama Khemis \\ (Rabiebenyahia33@yahoo.com) \\ ${ }^{3}$ Manajemen, Universitas Indonesia Timur \\ (Rishkamulya46@gmail.com)
}

\begin{abstract}
ABSTRAK
Jenis penelitian ini menggunakan penelitian asosiatif/kuantitatif yaitu merupakan penelitian yang bertujuan untuk mengetahui Analisis Sistem Pengawasan Pemberian Pembiayaan pada PT Bank Sulselbar Syariah Cabang Utama Makassar. Tehnik pengumpulan data melalui data primer berupa hasil kuesioner dan data sekunder berupa dokumen yang terkait dengan judul penelitian. Data yang diperoleh kemudian dianalisis melalui beberapa tahapan yang meliputi editing, koding, tabulasi data, dan diinterpretasikan menjadi sebuah deskriptif.

Hasil penelitian yang diperoleh bahwa Penanganan pembiayaan bermasalah yang dilakukan oleh PT Bank Syariah Sulselbar melalui staf penagihan dengan cara kombinasi antara reguler collection dan diskon margin memiliki success rate yang paling besar. Pada cara reguler collection staf penagihan mendatangi nasabah secara langsung, kemudian nasabah ditawarkan diskon margin dengan syarat nasabah tersebut memiliki kriteria sesuai yang telah ditetapkan oleh dewan direksi. Rata-rata tingkat non performing loan sebesar $14,91 \%$ artinya tingkat non performing loan pembiayaan musyarakah sebesar $14,91 \%$ dari total pembiayaan yang diberikan oleh Bank Syariah Sulselbar. Sedangkan maksimal tingkat non performing loan pembiayaan musyarakah terjadi pada bulan Maret 2015 sebesar 40,01\% yang diakibatkan oleh berkurangnya kemampuan bayar dari mudharib, dalam kasus ini yang akan terjadi Bank Syariah Sulselbar harus melakukan pencadangan yang tentu saja pada gilirannya mengurangi risiko kecukupan modal, sehingga tingkat non performing loan Bank Syariah Mandiri mengalami kenaikan dari triwulan sebelumnya. Hal ini disebabkan adanya kenaikan kredit kurang lancar
\end{abstract}

Kata Kunci: Pembiayaan, non performing loan, Bank Sulselbar Syariah Cab Makassar

\section{ABSTRACT}

This type of research uses associative / quantitative research which is a study that aims to find out the Supervision Analysis of Financing in PT Bank Sulselbar Syariah Main Branch of Makassar. Techniques for collecting data through primary data in the form of questionnaires and secondary data in the form of documents related to the research title. The data obtained is then analyzed through several stages including editing, coding, data tabulation, and interpreted into a descriptive. The results of the study obtained that the handling of problematic financing carried out by PT Bank Sulselbar Syariah through collection staff by means of a combination of regular collection and margin discounts has the greatest success rate. On a regular basis collection collection staff come to customers directly, then customers are offered a margin discount provided that the customer has the criteria set by the board of directors. The average level of non-performing loans is $14.91 \%$, which means that the non-performing level of musyarakah loans is $14.91 \%$ of the total funding provided by Sulselbar Syariah Bank. Whereas the maximum non-performing loan of musharaka financing occurred in March 2015 amounting to 40.01\% which was caused by the reduced ability to pay from 
mudharib, in this case the Sulselbar Syariah Bank would have to make a backup which of course in turn reduced the risk of capital adequacy the level of non-performing loans of PT Bank Sulselbar Syariah has increased from the previous quarter. This is due to an increase in credit is not smooth Keywords: Musyarakah, non Performing Loan, PT Bank Sulselbar Syariah

\section{PENDAHULUAN}

Di Indonesia pelopor berdirinya perbankan berdasarkan syariat islam atau pebanka syariah adalah Bank Muamalat Indonesia. Berdiri tahun 1991, bank ini diprakarsai oleh Majelis Ulama Indonesia (MUI) dan pemerintah serta dukungan dari Ikatan Cendekiawan Muslim Indonesia (ICMI) dan beberapa pengusaha muslim. Bank ini sempat terimbas oleh krisis moneter pada akhir tahun 90-an sehingga ekuitasnya hanya tersisa sepertiga dari modal awal. IDB kemudian memberikan suntikan dana kepada bank ini dan pada periode 19992002 dapat bangkit dan menghasilkan laba. Saat ini keberadaan bank syariah di Indonesia telah di atur dalam Undangundang yaitu UU No. 10 tahun 1998 tentang Perubahan UU No. 7 tahun 1992 tentang Perbankan. Hingga tahun 2007 terdapat 3 institusi bank syariah di Indonesia yaitu Bank Muamalat Indonesia, Bank Syariah Sulselbar dan Bank Mega Syariah.

Di Indonesia terdapat dua jenis perbankan yaitu bank konvensional yang cikal bakalnya dari perbankan peninggalan zaman penjajahan dan Perbankan syariah yang berdasarkan kondisi peradaban sekarang ini, sangat layak di tumbuh kembangkan diindonesia. Perbankan syariah saat ini sangat diminati masyarakat pada umumnya karna menganut nilai-nilai keadilan yang berdasarkan pada prinsipprinsip Syariat islam.

Machmud dan Rukmana (2010:4) mengemukakan bahwa "bank syariah adalah bank yang aktivitasnya meninggalkan masalah riba". Penghindaran bunga yang dianggap riba merupakan salah satu tantangan yang di hadapi dunia islam dewasa ini sedangkan,
Ahmad Ifham (2015:1) mengemukakan bahwa "bank syariah yaitu bank yang di jalankan berdasarkan syariah dengan kandungan ajaran islam yakni Aqidah, Akhlak, dan Syariah".

Bank berdasarkan prinsip syari'ah, seperti halnya bank konvensional juga berfungsi menjadi lembaga intermediasi yaitu lembaga yang sumber dananya dari masyarakat melalui tabungan atau investasi dan menyalurkan kembali kepada masyarakat untuk pembiayaaan.

Komposisi bagi hasil yang diterapkan oleh perbankan syariah perlu diperhatikan bahwa apakah dengan sistem tersebut dapat meningkatkan profitabilitas perusahaan, Namun fenomena yang terjadi saat ini yang menunjukkan bahwa profitabilitas yang dicapai menurun dalam tahun terakhir. Dengan adanya penurunan profitabilitas maka perlu dilakukan penelitian mengenai komposisi bagi hasil yang ditetapkan seringkali tidak optimal.

Dengan tidak optimalnya komposisi bagi hasil menyebabkan profitabilitas menurun, oleh karena itulah maka perlu dilakukan penelitian mengenai faktorfaktor yang mempengaruhi sistem bagi hasil. Hal ini perlu dilakukan untuk pengukuran mengenai faktor-faktor yang mempengaruhi komposisi bagi hasil. Maka penulis tertarik untuk mengadakan penelitian dengan judul "Analisis Sistem Pengawasan Pemberian Pembiayaan pada PT Bank SULSELBAR Syariah Cabang Utama Makassar".

\section{METODE PENELITIAN}

Peneliti melakukan analisa terhadap data yang telah diuraikan dengan menggunakan metode kualitatif dan 
kuantitatif, menggunakan rumus NPL (non performing loan), yaitu:

$$
\begin{aligned}
& \text { NPL }=\frac{k L+D+M}{L} \times 100 \% \\
& \text { Keterangan: } \\
& \mathrm{L} \quad=\text { Lancar } \\
& \mathrm{KL}=\text { Kurang lancar } \\
& \mathrm{D}=\text { Diragukan } \\
& \mathrm{M}=\text { Macet }
\end{aligned}
$$

Data mengenai tingkat non performing loan pembiayaan mudharabah dalam penelitian ini diperoleh dari laporan keuangan (neraca dan catatan atas laporan keuangan) per triwulanan dari September 2015 sampai September 2016. Variabel tingkat non performing loan pembiayaan mudharabah dapat dihitung dengan cara membandingkan jumlah non performing loan pembiayaan mudharabah dengan total kredit pembiayaan mudharabah. Secara matematis, besarnya tingkat non performing loan.

\section{PEMBAHASAN}

Bank Syariah Sulselbar menentukan jumlah pembiayaan bermasalah (Nn Performing Loan) yang meliputi pembiayaan yang digolongkan menjadi: dalam perhatian khusus, kurang lancar (KL), diragukan (D), dan macet (M). Perhitungan mengenai tingkat non performing loan pembiayaan mudharabah dijabarkan dalam tabel sebagai berikut:

Tabel. 1. Tingkat Non Performing Loan Pembiayaan Mudharabah

Laporan Keuangan per triwulan dari September 2015 sampai September 2017 Bank Syariah Sulselbar

(Dalam Jutaan Rupiah)

\begin{tabular}{|l|c|c|c|c|c|}
\hline \multicolumn{1}{|c|}{ Periode } & $\begin{array}{c}\text { Kurang } \\
\text { Lancar }\end{array}$ & Diragukan & Macet & $\begin{array}{c}\text { Total } \\
\text { Kredit } \\
\text { Yang } \\
\text { Diberikan }\end{array}$ & $\begin{array}{c}\text { Non } \\
\text { Performing } \\
\text { Loan }\end{array}$ \\
\hline Sep-15 & 7604 & 5597 & 13471 & 524494 & $5,08 \%$ \\
\hline Desember 2015 & 8019 & 2453 & 14223 & 466087 & $5,29 \%$ \\
\hline Maret 2016 & 7922 & 3668 & 14164 & 516183 & $4,98 \%$ \\
\hline Juni 2016 & 6538 & 3579 & 14729 & 466483 & $5,32 \%$ \\
\hline Sep-16 & 13045 & 5818 & 17196 & 441922 & $8,15 \%$ \\
\hline Desember 2016 & 1409 & 2399 & 3223 & 96926 & $7,25 \%$ \\
\hline Maret 2016 & 571 & 1888 & 3136 & 112723 & $4,96 \%$ \\
\hline Juni 2016 & 700 & 1663 & 3473 & 132953 & $4,38 \%$ \\
\hline Sep-16 & 991 & 3252 & 3748 & 165371 & $4,83 \%$ \\
\hline Desember 2006 & 579 & 2196 & 3395 & 170916 & $3,60 \%$ \\
\hline Maret 2017 & 677 & 1055 & 3541 & 189797 & $2 ., 77 \%$ \\
\hline Juni 2017 & 2889 & 2157 & 4026 & 232418 & $3,90 \%$ \\
\hline
\end{tabular}


Perolehan pembiayan Mudharabah bermasalah dapat terlihat dari tabel diatas dimana rata-rata tingkat non performing loan pembiayaan Mudharabah periode September 2015 sampai dengan September 2017 sebesar 3,28\%. Periode September 2015 besarnya tingkat non performing loan untuk pembiayaan mudharabah bermasalah adalah 5,08\% merupakan permulaan persentase yang cukup baik bagi Bank Syariah Sulselbar dimana Bank Syariah Sulselbar baru mengoperasionalkan pembiayaan Mudharabah ini kepada masyarakat. Namun, pada Desember 2015 tingkat non performing loan yang diperoleh mengalami kenaikan sebesar 0,21\% menjadi 5,29\% yang disebabkan oleh pihak Bank Syariah Sulselbar kurang berhati-hati dalam menilai calon debitur.

Pada Maret 2016, tingkat non performing loan yang diperoleh pada pembiayaan mudharabah mengalami penurunan sebesar $0,31 \%$ menjadi $4,98 \%$. Penurunan terjadi karena pihak bank semakin berhati-hati dalam memberikan pembiayaan kepada calon nasabah dengan cara membentuk tim restrukturisasi pembiayaan. Pada Juni 2005 tingkat non performing loan kembali mengalami peningkatan. Meskipun total pembiayaan mudharabah yang diberikan kepada calon nasabah menurun, hal ini disebabkan karena ketidakmampuan nasabah dalam mengelola pembiayaan yang diberikan oleh Bank Syariah Sulselbar yang antara lain disebabkan oleh ketidakmampuan nasabah mengelola perusahaannya.

Pada September 2016 kembali mengalami peningkatan yang sangat signifikan sebesar $2,83 \%$ menjadi $8,15 \%$. Peningkatan non performing loan pembiayaan mudharabah ini disebabkan banyaknya nasabah yang tidak mampu mengembalikan kredit karena terganggu kelancaran usaha sehingga tidak bisa lancar dalam hal pembayaran. Terganggunya kelancaran usaha nasabah tersebut disebabkan oleh situasi ekonomi dalam negeri yang buruk dan dilanda krisis moneter yang berkepanjangan.

Pada Desember 2016 sampai dengan Maret 2017 dapat dilihat bahwa tingkat non performing loan pembiayaan mudharabah menurun secara bertahap, meskipun total pembiayaan mudharabah yang disalurkan meningkat. Hal ini menunjukan bank semakin berhati-hati dalam memberikan pembiayaan mudharabah mengingat produk pembiayaan ini memiliki tingkat kegagalan yang besar, dimana bank memberikan modal $100 \%$ atas dana yang dibutuhkan debitur atau nasabah untuk dikelola.

Pada Juni 2017 terjadi peningkatan non performing loan kembali yaitu $3,90 \%$. Begitu pula pada September 2007, tingkat non performing loan meningkat sebesar 0,09\% menjadi 3,99\%. Hal ini terjadi dikarenakan meningkatnya pembiayaan yang disalurkan oleh Bank Syariah Sulselbar.

Data mengenai tingkat non performing loan pembiayaan musyarakah dalam penelitian ini diperoleh dari laporan keuangan (neraca dan catatan atas laporan keuangan) per triwulanan dari September 2015 sampai September 2017. Variabel tingkat non performing loan pembiayaan musyarakah dapat dihitung dengan cara membandingkan jumlah non performing loan pembiayaan musyarakah dengan total kredit pembiayaan musyarakah.

$\begin{array}{ccr}\text { Bank } & \text { Syariah } & \begin{array}{r}\text { Sulselbar } \\ \text { pembiayaan }\end{array}\end{array}$ bermasalah (Non Performing Loan) yang meliputi pembiayaan yang digolongkan menjadi: dalam perhatian khusus, kurang lancar (KL), diragukan (D), dan macet 
(M). Perhitungan mengenai tingkat non

dijabarkan dalam tabel sebagai berikut: performing loan pembiayaan musyarakah

Tabel 2.Tingkat Non Performing Loan Pembiayaan Musyarakah

Laporan Keuangan per triwulan dari September 2015 sampai September 2017 BankSyariah Sulselbar

\begin{tabular}{|c|c|c|c|c|c|}
\hline Periode & $\begin{array}{c}\text { Kurang } \\
\text { Lancar }\end{array}$ & Diragukan & Macet & $\begin{array}{c}\text { Total Kredit } \\
\text { yang } \\
\text { Diberikan }\end{array}$ & NPL \\
\hline Sep-15 & 9034 & 9580 & 15 & 49077 & $37.95 \%$ \\
\hline Desember 2015 & 14968 & 8397 & 1284 & 63624 & $38.74 \%$ \\
\hline Maret 2016 & 20417 & 40 & 9067 & 73786 & $40.01 \%$ \\
\hline Juni 2016 & 18781 & 2415 & 9607 & 118868 & $25.91 \%$ \\
\hline Sep-16 & 46314 & 1492 & 5905 & 256399 & $20.94 \%$ \\
\hline Desember 2016 & 8063 & 19366 & 8188 & 1442734 & $2.46 \%$ \\
\hline Maret 2016 & 16927 & 19548 & 8156 & 1755734 & $2.54 \%$ \\
\hline Juni 2016 & 1275 & 30407 & 13994 & 2029461 & $2.25 \%$ \\
\hline Sep-16 & 134114 & 24508 & 24120 & 2357386 & $7.75 \%$ \\
\hline Desember 2016 & 32546 & 110993 & 39184 & 2474350 & $7.38 \%$ \\
\hline Maret 2017 & 88233 & 77799 & 83552 & 2683862 & $9.29 \%$ \\
\hline Juni 2017 & 89517 & 106475 & 77662 & 3229612 & $8.47 \%$ \\
\hline Sep-17 & 87820 & 90388 & 111392 & 3549959 & $8.15 \%$ \\
\hline & & & & Rata-rata & $14,91 \%$ \\
\cline { 5 - 6 } & & & Max & $40,01 \%$ \\
\cline { 5 - 6 } & & & Min & $2,46 \%$ \\
\hline
\end{tabular}

Perolehan pembiayaan Musyarakah bermasalah dapat terlihat dari tabel diatas dimana rata-rata tingkat non performing loan pembiayaan Musyarakah periode September 2015 sampai dengan September 2017 sebesar 14,91\%. Periode September 2015besarnya tingkat non performing loan untuk pembiayaan Musyarakah bermasalah adalah 37,95\%. Tetapi pada Desember 2015, perolehan non performing loan mengalami peningkatan sebesar $0,74 \%$ menjadi $38,74 \%$. Hal ini disebabkan pengawasan internal bank yang longgar kepada mudharib. Pada Maret 2016 kembali mengalami peningkatan sebesar $1,27 \%$ menjadi 40,01\%. Peningkatan ini disebabkan oleh berkurangnya kemampuan bayar dari mudharib, dalam kasus ini yang akan terjadi Bank Syariah Sulselbar harus melakukan pencadangan yang tentu saja pada gilirannya mengurangi resiko kecukupan modal.

Pada Juni 2016 perolehan pembiayaan musyarakah bermasalah mengalami penurunan sebesar $14,1 \%$ menjadi $25,91 \%$, hal ini disebabkan semakin berhati-hatinya pihak bank dalam memberikan pembiayaan. Pada September 2015 kembali mengalami penurunan sebesar $4,97 \%$ menjadi $20,94 \%$ meskipun total pembiayaan yang diberikan pihak bank mengalami peningkatan. 
Pada Desember 2015 sampai dengan Juni 2016 dapat dilihat bahwa tingkat non performing loan pembiayaan Musyarakah menurun, meskipun total pembiayaan musyarakah meningkat dari Desember 2016 sampai dengan Juni 2016. Hal ini menunjukkan, meski suku bunga simpanan mengalami penurunan, namun sebagian masyarakat masih memilih pembiayaan Musyarakah sebagai salah satu alternatif investasi yang tidak memiliki resiko yang besar karena dana berasal dari kedua belah pihak (bank dan nasabah). Pada bulan September 2016 terjadi peningkatan non performing loan kembali yaitu $7,75 \%$. Hal ini disebabkan krisis moneter yang berkepanjangan di dalam negeri dan berakibat banyaknya nasabah (mudharib) atau perusahaan yang mendapatkan pembiayaan tidak mampu memenuhi kewajiban kepada bank. Kemudian Desember 2016 tingkat non performing loan kembali mengalami penurunan sebesar $0,37 \%$ menjadi $7,38 \%$. Hal ini disebabkan perbaikan kinerja industri perbankan yang cukup signifikan oleh Bank Syariah Sulselbar. Namun pada Maret 2017 mengalami peningkatan non performing loan menjadi 9,29\%, sebelum akhirnya pada Juni 2017 turun kembali menjadi $8,47 \%$, dan pada September 2017 tinggal 8,15\%. Naik turunnya Non Performing Loan Pembiayaan Musyarakah disebabkan oleh belum adanya perbaikan kinerja yang dilakukan Bank Syariah Sulselbar secara konsisten.

Sedangkan minimal tingkat non performing loan pembiayaan musyarakah terjadi pada bulan Desember 2015 yang berada di posisi dibawah rata-rata sebesar $2,46 \%$ yang disebabkan oleh semakin berhati-hatinya pihak bank dalam memberikan pembiayaan dan membuat tim restrukturisasi untuk menyelamatkan pembiayaan atas debitur yang masih memiliki prospek usaha namun diperkirakan akan mengalami kesulitan dalam membayar bagi hasil. Hal ini ditunjukkan oleh adanya penurunan yang sangat besar terhadap kredit kurang lancar yang sebesar $474,40 \%$. Walaupun pada kredit yang diragukan mengalami kenaikan sebesar 119,79\% dan kredit macet mengalami peningkatan sebesar $38,66 \%$. Tetapi penurunan kredit kurang lancar masih lebih besar dibandingkan kenaikan kedua kriteria non performing loan.

\section{KESIMPULAN DAN SARAN}

Berdasarkan hasil penelitian pada bab sebelumnya, maka dapat disimpulkan bahwa:

1. Penanganan pembiayaan bermasalah yang dilakukan oleh PT Bank Syariah Sulselbar melalui staf penagihan dengan cara kombinasi antara reguler collection dan diskon margin memiliki success rate yang paling besar. Pada cara reguler collection staf penagihan mendatangi nasabah secara langsung, kemudian nasabah ditawarkan diskon margin dengan syarat nasabah tersebut memiliki kriteria sesuai yang telah ditetapkan oleh dewan direksi.

2. Rata-rata tingkat non performing loan sebesar $14,91 \%$ artinya tingkat non performing loan pembiayaan musyarakah sebesar $14,91 \%$ dari total pembiayaan yang diberikan oleh Bank Syariah Sulselbar. Sedangkan maksimal tingkat non performing loan pembiayaan musyarakah terjadi pada bulan Maret 2015 sebesar 40,01\% yang diakibatkan oleh berkurangnya kemampuan bayar dari Mudharib, dalam kasus ini yang akan terjadi Bank Syariah Sulselbar harus melakukan pencadangan yang tentu saja pada gilirannya mengurangi risiko 
kecukupan modal, sehingga tingkat non performing loan Bank Syariah Mandiri mengalami kenaikan sebesar $1,27 \%$ dari triwulan sebelumnya. Hal ini disebabkan adanya kenaikan kredit kurang lancar sebesar 36,40\%, diragukan sebesar 99,52\%, dan untuk kredit macet sebesar 606,15\%. PT Bank Syariah Sulselbar harus konsisten dengan aturan yang ada dalam menyeleksi nasabah pembiayaan. Selain itu, PT Bank Syariah Sulselbar harus mengurangi penyaluran pembiayaan yang sifatnya konsumtif. Karena pembiayaan yang sifatnya konsumtif tidak ada perputaran uang, dana yang diterima sehingga nasabah akan mengalami kesulitan dalam pengembalian dana pembiayaan.

\section{UCAPAN TERIMA KASIH}

Dalam menyelesaikan karya ilmiah ini, penulis banyak mendapat bantuan, informasi, serta dukungan dari berbagai pihak. Terutama dukungan berupa informasi yang akurat dari pihak PT Bank Syariah Sulselbar. Penulis mengucapkan banyak terima kasih

\section{DAFTAR PUSTAKA}

Darsono, Astiyah.2017. Perbankan Syariah di Indonesia. Jakarta: PT Raja Grafindo Persada.

Fahmi. 2014.Pengantar Perbankan Teori dan Aplikasi.Bandung: Alfabeta.

Ifham. 2015. Ini Lho Bank Syariah. Jakarta: PT Gramedia Pustaka Utama.

Machmud, Rukmana. 2010. Bank Syariah. Jakarta: PT Gelora Aksara Pratama.

Sugiyono. 2012. Metode Penelitian Kuantitatif Kualitatif dan $R$ \& D.Bandung: Alfabeta.
Rikiabdulrahman. 2014. jenis-jenis akad pembiayaan

bank..http://blogspot.co.id.

Diakses pada tanggal 8 Juni 2017.

Inu05.2016.unit usaha syariah uus.http://blogspot.com.

Diakses pada tanggal 10 Juni 2017.

scholar.bank pembiayaan rakyat syariah.https://google.co.id.

Diakses pada tanggal 10 Juni 2017.

Tipsserbaserbi.2015.Pengertian dan kegiatan bank umum.http://blogspot.co.id. Diakses pada tanggal 11 Juni 2017.

Rahman.manajemen perbankan.https://bimbelskrip si.com. Diakses pada tanggal 12 Juni 2017.

Syafi'IAntonio,Muhammad.2001.Bank Syariah DariTeori Ke Praktek.Jakarta: Gema Insani.

Antonio, Perwataatmadja. 2008. Apa dan Bagaimana Bank Islam.Yogyakarta: Dana Bhakti Wakaf.

Arifin, Zainul. 2002. Dasar-Dasar Manajemen Bank Syariah.Jakarta: Alfabet

Dendawijaya, Lukman. 2005. Manajemen Perbankan. Bogor :Ghalia Indonesia.

Hasibuan, Malayu. 2008. Dasar-Dasar Perbankan. Jakarta: Bumi Aksara.

Karim, A. Adimarwan. 2004. Bank Islam, Jakarta: Rajagrafindo Persada

Muhammad. 2004. Manajemen Dana Bank Syariah. Yogyakarta: Ekonisia.

Nurhayati, Sri, Wasilah. 2008. Akuntansi Syariah di Indonesia.Jakarta: Salemba Empat.

Nazir, Habib, DR. Hasanuddin Muhammad. 2004. 
Ensiklopedi Ekonomi dan Perbankan Syariah, Bandung: Kaki Langit.

Republik Indonesia. 1992. UU No. 7 Tahun 1992 Tentang Perbankan.

Sutrisno. 2003. Manajemen Keuangan, Teori, Konsep dan Aplikasi. Yogyakarta: Ekonisia.

Syamsuddin, Lukman. 2002. Manajemen Keuangan Perusahaan, Jakarta: Rajawali Pers. 